\title{
A conjugation-like mechanism for prespore chromosome partitioning during sporulation in Bacillus subtilis
}

\author{
Ling Juan Wu, Peter J. Lewis, Rudolf Allmansberger, ${ }^{1}$ Philippe M. Hauser, ${ }^{2}$ and Jeffery Errington \\ Sir William Dunn School of Pathology, University of Oxford, Oxford OX1 3RE, UK
}

\begin{abstract}
Spore formation in Bacillus subtilis begins with an asymmetric cell division that superficially resembles the division of vegetative cells. Mutations in the spoIIIE gene of B. subtilis partially block partitioning of one chromosome into the smaller (prespore) compartment of the sporulating cell. Point mutations that specifically block prespore chromosome partitioning affect a carboxy-terminal domain of SpoIIIE that shows significant sequence similarity to the DNA transfer (Tra) proteins of several conjugative plasmids of Streptomyces. In wild-type sporulating cells, the prespore chromosome passes through an intermediate stage resembling the state in which spoIIIE mutant cells are blocked. The prespore chromosome is then transferred progressively through the newly formed spore septum. We propose that translocation of the prespore chromosome occurs by a mechanism that is functionally related to the conjugative transfer of plasmid DNA.
\end{abstract}

[Key Words: spoIIIE gene; cell division; Tra proteins; septation; nucleoid]

Received March 6, 1995; revised version accepted April 11, 1995.

Successful cell division requires an accurate mechanism for partitioning the products of a round of DNA replication to the daughter cells created by formation of a division septum. It is generally agreed, at least for Escherich ia coli, that DNA partitioning is an active process that usually occurs before the septum begins to be formed (Donachie 1993). Despite many years of work, the mechanism of chromosome partitioning remains obscure. Although it has been suggested that newly synthesized sister chromosomes move apart abruptly, inferring the existence of a mitotic apparatus (Hiraga et al. 1989; Hiraga 1992), the most recent results indicate that partitioning occurs progressively during cell growth (van Helvoort and Woldringh 1994).

Cell division in vegetative Bacillus subtilis closely resembles that of $E$. coli in morphological terms, and several gene products needed for division seem to be conserved in both organisms (Beall et al. 1988; Yanouri et al. 1993). B. subtilis also undergoes a modified cell division, during the process of sporulation. Again, this process seems related to vegetative division morphologically (Hitchins and Slepecky 1969), and the formation of the septum requires gene products in common with vegetative division (Beall and Lutkenhaus 1991, 1992; Levin and Losick 1994). However, during sporulation the division septum is placed close to one pole of the parent cell and one of the newly formed chromosomes must un-

Present addresses: ${ }^{1}$ Lehrstuhl für Mikrobiologie, Universität ErlangenNuernberg, D-91058 Erlangen, Germany; ${ }^{2}$ Institut de Génétique et Biologie microbiennes, 1005 Lausanne, Switzerland. dergo an extreme movement to achieve its near polar position (Ryter 1965).

We showed recently that DNA partitioning during sporulation specifically requires the product of the spoIIIE gene (Wu and Errington 1994). In spoIIIE mutants the spore septum forms in its normal asymmetric location, but only a minor proportion $(\sim 30 \%)$ of the prespore chromosome is localized in the small compartment. The remainder is located incorrectly in the larger compartment, along with the whole of the mother cell chromosome. The SpoIIIE phenotype, with the prespore nucleoid bisected by the septum, could arise by failure of the chromosome to move to the pole of the cell before septation or by failure of the chromosome to be translocated through the septum after it has formed around the nucleoid.

Soon after the formation of the spore septum, the $\sigma^{F}$ transcription factor becomes active specifically in the prespore compartment (Margolis et al. 1991; Partridge et al. 1991). The classic spoIIIE36 mutation was once thought to block $\sigma^{F}$ activation, but it now appears that the effects on gene expression are an indirect consequence of the impairment in DNA partitioning: In the mutant, $\sigma^{\mathrm{F}}$ becomes active specifically in the prespore, as usual, but most $\sigma^{\mathrm{F}}$-dependent genes fail to enter this compartment. Despite the fact that the prespore chromosome has been trapped (or bisected) by the septum, the two compartments seem to be physiologically separated in this mutant. Surprisingly, however, a spoIIIE null mutation also results in inappropriate release of $\sigma^{\mathrm{F}}$ in both the prespore and the mother cell, indicating that 
spoIIIE is also required for correct localization of $\sigma^{\mathrm{F}}$ activity.

To improve our understanding of SpoIIIE function, we have now characterized the phenotypic effects of a collection of spoIIIE mutants. The class I mutations, which are defective specifically in prespore DNA partitioning (i.e., they do not affect $\sigma^{F}$ localization), all lie in the carboxy-terminal coding region of the gene and are mainly missense mutations. The carboxy-terminal domain of SpoIIIE shows striking sequence similarity to the transfer (Tra) proteins of various conjugative plasmids of Streptomyces. By analogy to conjugation, SpoIIIE could work by driving the major part of the prespore chromosome through the nascent spore septum. In accordance with this idea, we have shown that in wild-type sporulating cells, the prespore chromosome enters the prespore compartment after septation, in a progressive manner. The results indicate that prespore chromosome partitioning proceeds by a mechanism that is quite different from the one that normally operates in vegetative cells and instead may be functionally related to conjugative DNA transfer.

\section{Results}

spoIIIE mutations that specifically block prespore DNA partitioning all affect a carboxy-terminal domain of the protein product

We reported previously that the classically isolated spoIIIE36 mutation specifically blocks partitioning of the prespore DNA, with little immediate effect on gene expression in either of the cells. The early cell-specific transcription factors $\sigma^{\mathrm{F}}$ and $\sigma^{\mathrm{E}}$ are activated correctly, in their appropriate compartments, but some prespore-specific genes, such as $g p r$, do not become active because they fail to enter the prespore compartment $(\mathrm{Wu}$ and Errington 1994). An in vitro-constructed null mutation, spoIIIE647, caused a similar defect in prespore DNA partitioning, but it also affected $\sigma^{F}$ activation, which occurred inappropriately in the mother cell, as well as in the prespore (Wu and Errington 1994). Our laboratory strain collection contained nine other alleles of spoIIIE, as judged by complementation with the spoIIIE ${ }^{+}$transducing phage $\phi 105 J 115$ (East and Errington 1989). The mutations were all transformed into an isogenic background, and their effects on DNA partitioning during sporulation were examined. All blocked prespore DNA partitioning in a manner indistinguishable from the effects of the spoIIIE36 and spoIIIE647 mutations described previously (results not shown; Wu and Errington 1994). Transformation of each mutant with a spoIIIG''lacZ fusion (plasmid pSG139) allowed the effects on $\sigma^{F}$ localization to be assessed, because this fusion lies in a region of the chromosome that fails to enter the prespore compartment in spoIIIE mutants. Mutations spoIIIE47, spoIIIE82, spoIIIE601, spoIIIE602, spoIIIE603, and spoIIIE629 (designated class I) behaved like spoIIIE36, in conferring a $\mathrm{Lac}^{-}$phenotype, indicating that $\sigma^{\mathrm{F}}$ activity was localized correctly in the prespore. The remaining three mutations, spoIIIE604, spoIIIE644, and spoIIIE649, like spoIIIE647, produced blue colonies and were designated class II mutations. A full description of the phenotypic effects of the various mutations will be described elsewhere.

The DNA sequences of the class I mutant alleles should give information on the region of SpoIIIE involved specifically in prespore chromosome partitioning. Integration plasmids pSG255 and pSG801 covering the amino- and carboxy-terminal coding portions of spoIIIE were first used to determine in which half of the gene each of the mutations lay. Then, plasmids carrying the mutations were excised from the chromosome and recovered by transformation of $E$. coli. The spoIIIE $913 \mathrm{mu}$ tant allele (see below) was recovered directly from the chromosome by PCR amplification.

As shown in Table 1, the previously isolated class I spoIIIE mutations (allele numbers $<900$ ) all lay in the carboxy-terminal coding region of spoIIIE (Fig. 1, below). Most were point mutations that would produce single amino acid substitutions. Mutation spoIIIE36 consisted of a cluster of closely linked missense changes. Mutation spoIIIE82 was a nonsense mutation, but it lay close to the carboxy-terminal coding end of the gene. In contrast, the class II mutations were all nonsense or frameshift mutations that would severely truncate the protein product.

Table 1. Sequences of spoIIIE mutations

\begin{tabular}{|c|c|c|}
\hline Mutation & $\begin{array}{l}\text { DNA squence } \\
\text { alteration }^{\mathrm{a}}\end{array}$ & $\begin{array}{l}\text { Effect on SpoIIIE } \\
\text { protein }^{b}\end{array}$ \\
\hline \multicolumn{3}{|l|}{ Class I } \\
\hline spoIIIE36 & $\begin{array}{l}\text { G2352A, C2390G, } \\
\text { G2391C }\end{array}$ & $\begin{array}{l}\text { V427M, N439K, } \\
\text { V440L }\end{array}$ \\
\hline spoll1E47 & G3055A & G661D \\
\hline spoIIIE82 & $\mathrm{C} 3162 \mathrm{~T}$ & Q697* \\
\hline spoIIIE 602 & G3028A & G652D \\
\hline spoIIIE629 & G2305A & G411E \\
\hline SpOIIIE 911 & $\mathrm{C} 2254 \mathrm{~T}$ & A394V \\
\hline SPOIIIE913 & G2199A & G376R \\
\hline \multicolumn{3}{|c|}{ Class II } \\
\hline spoIIIE604 & $\mathrm{C} 1377 \mathrm{~T}$ & Q102* \\
\hline spoIIIE644 & $\Delta(\mathrm{G} 2601)$ & $\begin{array}{l}\text { 510, frameshift, }+8 \\
\text { aa }\end{array}$ \\
\hline spoIIIE647 & $\Omega(1184-3039:: a p h A-3)$ & 37, insertion, $+11 \mathrm{aa}$ \\
\hline spoIIIE649 & (ATCA)2268|GG) & $\begin{array}{l}\text { 397, frameshift, }+14 \\
\text { aa }\end{array}$ \\
\hline
\end{tabular}

${ }^{a}$ Numbering according to the sequence described by Butler and Mandelstam (1987), incorporating the correction by Foulger and Errington (1989). The wild-type and mutant bases are given, respectively, before and after the number indicating the position of the mutation in the sequence. $(\Omega)$ Insertion; $(\Delta)$ deletion. ${ }^{b}$ Numbering according to Foulger and Errington (1989). For amino acid substitutions, the letters before and after the number giving the position represent, respectively, the residues in the wild-type and the mutant proteins. For frameshift and insertional mutations, the number indicates the last unchanged residue in the protein. The number of additional amino acids (aa) added after the site of the mutation are given. (*) Stop codon. 
Absence of class I mutations in the amino-terminal coding region of spollIE

It was striking that the class I mutations were all located in the carboxy-terminal coding half of spoIIIE (Fig. 1). To test whether similar mutations could be isolated in the amino-terminal half of the gene, plasmid pSG255, containing this region, was treated with $N$-methyl- $N^{\prime}$-nitro$N$-nitrosoguanidine (NTG) in E. coli and the purified mutagenized plasmid DNA was transformed into strain 687 , which carries a lacZ fusion to the $\sigma^{\mathrm{F}}$-dependent spoIIIG gene and thus forms blue colonies on plates containing X-gal. From $\sim 5000$ chloramphenicol-resistant transformants / which would contain Campbell-integrated copies of the plasmid), two mutants showing a white colony color phenotype on plates containing X-gal were isolated. Transducing phage $\phi 105 J 115$, carrying the wildtype spoIIIE gene, was used to check that the new mutations lay in spoIIIE; lysogeny with the phage resulted in the restoration of the blue colony color phenotype. In a parallel experiment, the mutagenized plasmid DNA was also transformed into wild-type strain SG38 and $\mathrm{Spo}^{-}$mutants were isolated. From $\sim 8000$ transformants, 23 mutants were isolated. A spoIIIG'-lacZ fusion was introduced into each of the mutants by transformation with chromosomal DNA from strain 687, so that the effects of the mutations on $\sigma^{\mathrm{F}}$-dependent transcription could be determined. Only one of the mutants (containing a mutation designated spoIIIE913) showed a block in spoIIIG'-lacZ expression, as expected for a class I mutation.

The three class I mutations derived by mutagenesis of pSG255 were cloned and sequenced. The two mutations derived by direct transformation of strain 687 had identical lesions, so only one, designated spoIIIE911, will be considered further. Both spoIIIE911 and spoIIIE913 were missense mutations lying close to the downstream end of the spoIIIE insert in PSG255 (Table 1). The locations of these mutations close to the cluster of previously isolated class I mutations suggest that the domain defined by the class I mutations does not extend far into the insert in plasmid pSG255 and/or that only the aminoterminal part of SpoIIIE is important for the localization of $\sigma^{\mathrm{F}}$ activity.

The carboxy-terminal domain of SpoIIIE resembles the Tra proteins from several conjugative plasmids of Streptomyces

The mutations specifically blocking prespore chromosome partitioning all lay in the C-terminal coding half of spoIIIE. As one way of elucidating the function of this domain, we searched for sequence similarities in protein sequence data bases. Strong sequence similarities were reported previously between SpoIIIE and chromosomal genes from diverse bacteria, Coxiella burnetii (Oswald and Thiele 1993) and Campylobacter jejuni (Miller et al. 1994). Unfortunately, the functions of these genes are not yet known. Among the sequences showing lower but still highly significant similarity scores to SpoIIIE were four proteins from plasmids of another Gram-positive bacterium, Streptomyces. As shown in Figure 2, the proteins could be aligned with SpoIIIE over a carboxy-terminal region of $\sim 500$ amino acids. The sequences were particularly closely related over a central region of $\sim 200$ amino acids. This region coincided with the most highly conserved part of SpoIIIE as compared with the two chromosomal homologs (Fig. 2). The central region included the A and B motifs (Walker et al. 1982) that are highly conserved in proteins that bind ATP (Saraste et al. 1990). However, these short motifs represented only a small proportion of the highly conserved region, so it is unlikely that the sequence similarities simply reflect a common NTP-binding function.

The plasmids encoding the proteins related to SpoIIIE all mediate conjugation. The mechanism of conjugation in Streptomyces differs from that of the more familiar $F$ system of $E$. coli in that it requires fewer plasmid-encoded products. In fact, in three of the four cases, the

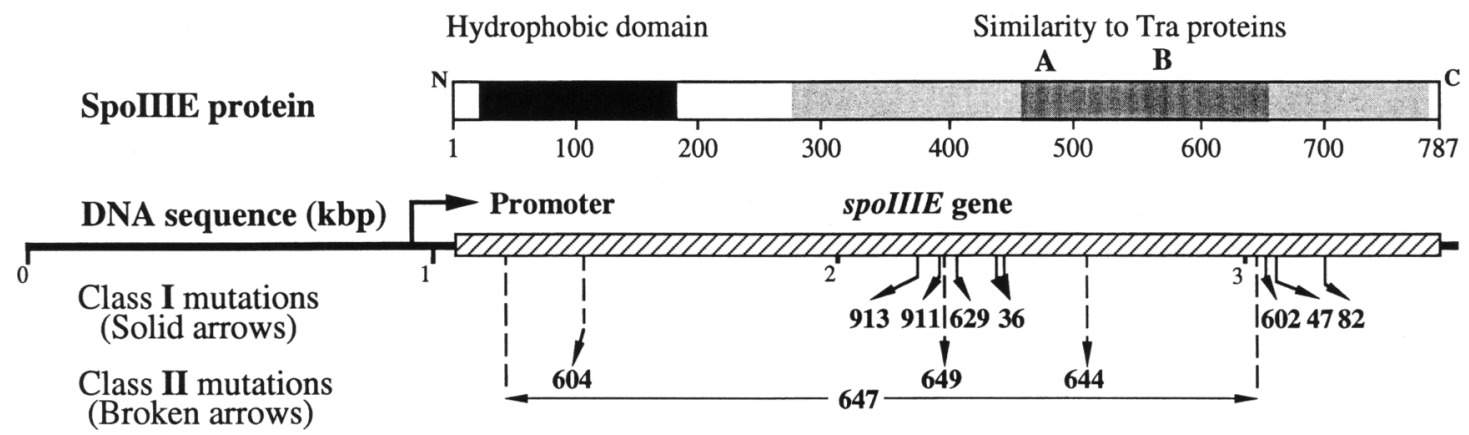

Figure 1. Locations of spoIIIE mutations and consequences for the SpollIE protein. (Top) The SpoIIIE protein, with the scale indicated in numbers of amino acids. A hydrophobic region and the regions of similarity between SpoIIIE and the Tra proteins of serveral plasmids from Streptomyces (see Fig. 2) are shaded. In the latter case, the intensity of shading indicates the degree of similarity. $(A, B)$ The positions of the ATP-binding motifs (Walker et al. 1982; Saraste et al. 1990) in this highly conserved region. (Bottom) The spoIIIE gene (sequence from Butler and Mandelstam 1987; Foulger and Errington 1989; scale in kb), with the locations of the spollIE mutations shown below. 


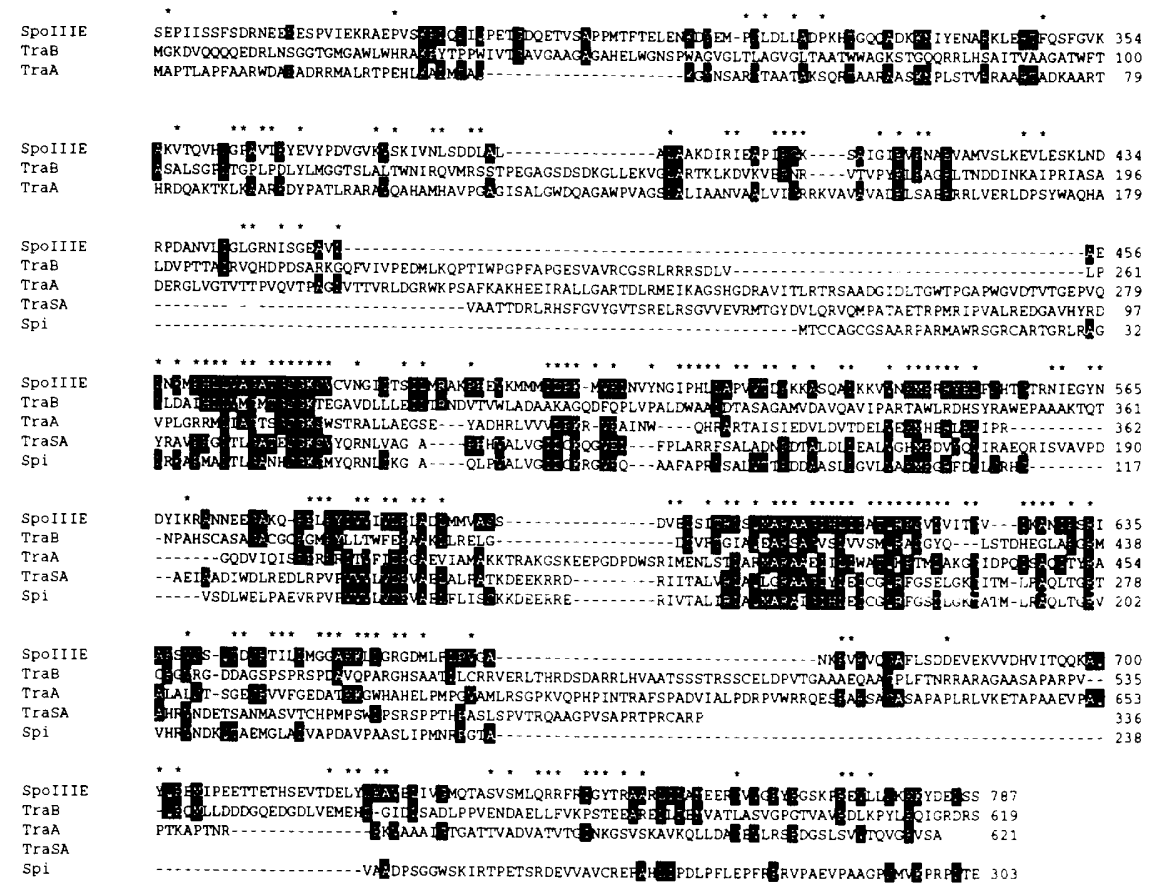

Figure 2. Sequence similarities between SpolIIE and proteins encoded by conjugative plasmids. Asterisks (*) over the SpoIIIE sequence denote residues that are identical in two chromosomally encoded genes that are closely related to SpoIIIE (see text). MACAW was used to identify blocks of significant sequence similarity between SpoIIIE and the Tra proteins. The final alignment was optimized manually. Residues that are identical in both SpoIIIE and one or more of the Tra proteins are highlighted. The protein sequences aligned with SpoIIIE [787 amino acids; Butler and Mandelstam 1987; Foulger and Errington 1989; protein infomation resource (PIR), SO9411) were Spi (303 amino acids; PIR, JC1485) from pSAl.1 of Streptomyces cyaneus (Tomura et al. 1993); TraSA [336 amino acids; European Molecular Biology Laboratory (EMBL), Z19593] from pSAM2 of Streptomyces ambofaciens (Hagège et al. 1993); TraB $(652$ amino acids; GenBank, D14281) from pSN22 of Streptomyces nigrifaciens (Kataoka et al. 1991); and TraA (621 amino acids; PIR, P22409) from pII101 of Streptomyces lividans (Kendall and Cohen 1988). gene related to spoIIIE has been shown to carry out the single function needed for DNA transfer (Kendall and Cohen 1988; Kataoka et al. 1991; Hagège et al. 1993). Figure 1 shows that the region of sequence similarity to the Tra proteins coincides with the region of SpoIIIE in which the class I mutations all lie.

\section{Prespore chromosome partitioning occurs postseptation in wild-type sporulating cells}

Our previous observations of spoIIIE mutants indicated a role for SpoIIIE in chromosome partitioning but not whether the protein acted before or after septation (Wu and Errington 1994). The sequence similarity to the Tra proteins suggested that SpoIIIE might drive prespore chromosome transfer through the nascent spore septum in a conjugation-like manner. A prediction of this model was that in wild-type cells formation of the spore septum should occur before the prespore compartment becomes filled with DNA. The timing of prespore DNA partitioning has not been directly compared with that of asymmetric septation. To do this, we used a newly developed ethanol fixation procedure to visualize the septa (see $\mathrm{Ma}$ terials and methods) and used fluorescence microscopy and a DNA-specific dye (Setlow et al. 1991) to determine the DNA contents of newly formed prespore compartments. Figure 3A illustrates the detection of central and asymmetric septa in wild-type sporulating cells. In accordance with our new ideas on the function of SpoIIIE protein, most cells with clear asymmetric septa had relatively small and rather variable amounts of DNA in the prespore compartment. Quantitation of the amounts of segregated DNA in such cells confirmed that few contained fully segregated chromosomes: Most contained $\sim 30 \%-70 \%$ of a chromosome equivalent (Fig. 3A,C). To exclude the possibility that the asymmetric septa were optical artifacts generated in some way by partitioning of the prespore chromosomes, we examined vegetative cells of a minicell-producing mutant of $B$. subtilis (SG10). The minicells made by these mutants are prespore-like in size and shape, and they too originate by near polar division. As shown in Figure 3E, the polar septa made by these organisms were readily detectable by the microscopic methods used to observe prespore septa, despite the fact that they were devoid of DNA (Fig. $3 F$ ). Polar septa were not detected in vegetative cells of a nonminicell mutant (results not shown).

The demonstration that many sporulating cells with visible spore septa contained only partially segregated chromosomes strongly suggested that septation precedes chromosome partitioning in sporulating cells. The fact that there were few, if any, cells with $<30 \%$ of the chromosome compartmentalized in the prespore accords with our previous suggestion (Wu and Errington 1994) that the first step in partitioning involves chromosome attachment to the cell pole, leading to the entrapment of $-30 \%$ of the chromosome in the newly formed small compartment. The near absence of cells with apparent prespore DNA contents of $>70 \%$ was either the result of the systematic underestimation of DNA content, which occurs with increasing levels of DNA condensation (Setlow et al. 1991; P.M. Hauser and J. Errington, unpubl.), or the disappearance of the septa, resulting from the further development of the prespore. 

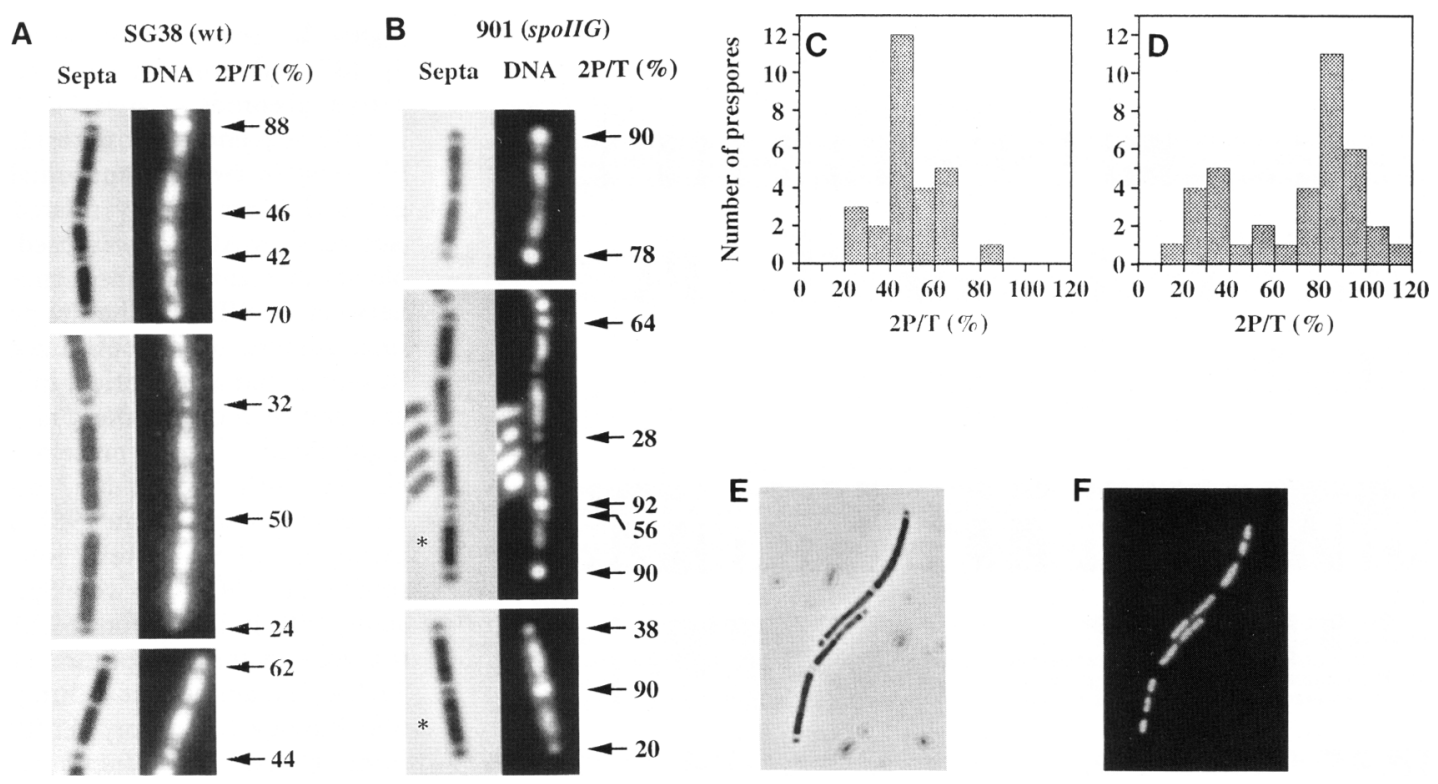

Figure 3. Septation and DNA partitioning in sporulating cells. $|A|$ Wild-type strain SG38. $(B)$ spollG mutant strain 901 . (Note that under these conditions, B. subtilis cells typically grow in chains.) The septa of sponlating cells taken 75 or 90 min after induction of sporulation were visualized by ethanol fixation and phase-contrast microscopy. Fluorescence microscopy of the same cells stained with DAPI allowed the DNA contents of the prespore compartments to be measured. The relative DNA content of each small prespore compartment $(\mathrm{P})$ was determined as a percentage of that of the whole cell $(\mathrm{T})$, by measuring the fluorescence intensity as described previously (Wu and Errington 1994). The numbers obtained were multiplied by a factor of 2 so that they express the amount of DNA segregated as a fraction of one chromosome equivalent, there being a total of two chromosomes per sporulating organism (Setlow et al. 1991). $(C, D)$ Frequency histograms plotted using data similar to that illustrated in $A$ and $B$, respectively. $(E, F)$ Phase-contrast and fluorescence micrographs, respectively, showing the detection of anucleate minicells by the divIVB mutant of $B$. subtilis (strain SG10). Microscopic magnification, $2500 \times$.

As a further test of the relative timing of septation and prespore chromosome partitioning, we repeated the experiment in a spoIIG mutant strain, in which prespore chromosome partitioning occurs sequentially at both poles of the sporulating organism (Lewis et al. 1994), and septa remain visible because engulfment is blocked. Again, a substantial proportion of the prespores demarcated by asymmetric septa exhibited relatively low DNA contents (Fig. 3B). Moreover, cells that had clear septa at both poles (examples are starred in Fig. 3B) often contained a considerable amount of DNA in the large central compartment: This was usually associated with a correspondingly smaller amount of DNA in the adjacent prespore compartment, indicating that partitioning was incomplete (Fig. 3B). The apparent DNA contents of these cells were often close to that of a whole chromosome, for reasons mentioned above.

These results strongly supported the view that the main phase of prespore chromosome partitioning occurs after asymmetric septum formation is well under way or near to completion.

SpoIIIE can drive DNA translocation through a previously formed spore septum

Although comparison of the kinetics of septum formation, as revealed by electron microscopy (Partridge and
Errington 1993) or ethanol fixation (Hauser and Errington 1995), suggested that the latter showed only septa that were complete or near to completion, it was important to exclude the possibility that chromosome partitioning was occurring when the septal annulus was still quite large. We reported previously that in the presence of a spoIIIE mutation septation appears to proceed to completion but the prespore chromosome fails to segregate properly and segments of the chromosome lie on either side of the septum (Wu and Errington 1994). Assuming that the DNA is not severed by the closing septum, there must be a discontinuity in the septum. To look for such a discontinuity, or pore, in the septum, previously we used electron microscopy to examine cells of a spoIIG spoIIIE36 double mutant, in which septa form at both poles of the sporangium and further development of the septum is blocked. The proportion of cells with a visibly discontinuous septum was very small $(<5 \%)$ and equivalent to that of the spoIIIE ${ }^{+}$control (Wu and Errington 1994). A few cells with incomplete septa were expected, being caught in the process of forming the septum. Because the sections that we examined were about one-tenth of a cell diameter thick, we estimate that if a "pore" remains in the septa of spoIIIE mutant cells, it represents only a small fraction of a cell diameter. We reasoned that if these mutant cells were trapped at an intermediate stage of partitioning, 
Table 2. Rescue of prespore chromosome partitioning in a spoIIIE mutant by infection with $\phi 105 / 115$ (spoIIIE ${ }^{+}$)

\begin{tabular}{|c|c|c|c|}
\hline \multirow{2}{*}{$\begin{array}{l}\text { Infecting } \\
\text { phage }\end{array}$} & \multicolumn{3}{|c|}{$\begin{array}{l}\text { Frequency of rescue of prespore } \\
\text { chromosome partitioning }\end{array}$} \\
\hline & $t_{3.5}^{\mathrm{b}}$ & $t_{4.5}$ & $t_{5.5}$ \\
\hline $\begin{array}{l}\text { None } \\
\phi 105 J 106\end{array}$ & $<0.2(79)$ & $\begin{array}{l}<0.2(77) \\
<0.2(76)\end{array}$ & $\begin{array}{l}<0.2(84) \\
<0.2(80)\end{array}$ \\
\hline$\phi 105 J 115$ & & $9 \quad(78)$ & $16\langle 80\rangle$ \\
\hline
\end{tabular}

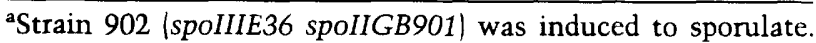
After $3.5 \mathrm{hr}\left(t_{3.5}\right)$, the culture was divided into three portions, which were infected with the appropriate phage or left uninfected. Most of the cells of this mutant had formed septa at both poles at this time, but as shown previously $(\mathrm{Wu}$ and Errington 1994), the majority of their DNA was located in the central compartment, rather than in the polar prespore compartments. At intervals, samples were examined by phase-contrast and fluorescence microscopy. Cells in which partitioning was at least partially rescued (prespore nucleoid brighter than that of the central compartment; a conservative estimation), were counted and presented as a percentage of the total cells viewed. The total frequency of sporulation (percentage of cells with at least one spore septum; either rescued or not rescued) is given in parentheses.

'Time after induction of sporulation; phage was added at $t_{3.5}$.

because of the absence of functional SpoIIIE protein, it might be possible to drive partitioning of the trapped chromosomes by providing them with the wild-type protein. We tested this idea by inducing sporulation in a culture of the double mutant strain; then after $3.5 \mathrm{hr}$ (as in the experiments reported previously), we infected one aliqout of the culture with a recombinant transducing phage, $\phi 105$ J115, carrying the wild-type spoIIIE gene (spoIIIE should still be expressed at this time; Foulger and Errington 1989). A second aliquot of the culture was infected with the vector phage $\phi 105 \mathrm{~J} 106$, with no spoIIIE gene, at a similar multiplicity of infection (m.o.i. $\sim 5.0)$. $\phi 105$ is known to be able to infect sporulating cells but does not undergo a lytic cycle (Osburne and Sonenshein 1976). Samples of both infected cultures and an uninfected aliquot were sampled at intervals and examined by phase-contrast and fluorescence microscopy (summarized in Table 2).

The $t_{3.5}$ time point was chosen because most cells that are capable of initiating sporulation have done so by this stage. At the time of infection, the majority of cells thus showed a typical "disporic" phenotype, with septa at both poles, but in keeping with the effects of the spoIIIE36 mutation, the majority of the DNA was located in the large central compartment, with only a minor component located in each of the prespores (Fig. $4 A, B \mid$. Infection with the control phage, $\$ 105 / 106$, had little effect on the appearance of the cells (Fig. 4C,D). However, $1 \mathrm{hr}$ after infection with $\phi 105) 115$ (spoIIIE ${ }^{+}$), the culture contained cells in which prespore chromosome partitioning appeared to have been partially completed (Table 2). After $2 \mathrm{hr}$, numerous cells of this type were evident (Fig. 4E,F), together with some cells in which partitioning was complete at both poles. That the latter cells contained fully segregated chromosomes was confirmed by measurement of their fluorescence relative to that of the nucleoids of a standard preparation of cells (data not shown). The cells in which chromosome partitioning was rescued were too numerous to be explained by the action of wild-type SpoIIIE prior to septation in a subpopulation of cells that were late in initiating sporulation: The number of sporulating cells showed only a slight increase over the $2-\mathrm{hr}$ incubation period in all three cultures (Table 2).

These results strongly suggest that prespore chromosome partitioning can occur after the presumptive aperture in the spore septum has closed to the point where it cannot be detected by conventional electron microscopic methods.

\section{Prespore chromosome partitioning is dependent on asymmetric septation}

If partitioning of the prespore chromosome occurs through the nascent septum, it seemed possible that formation of the septum might be required for chromosome

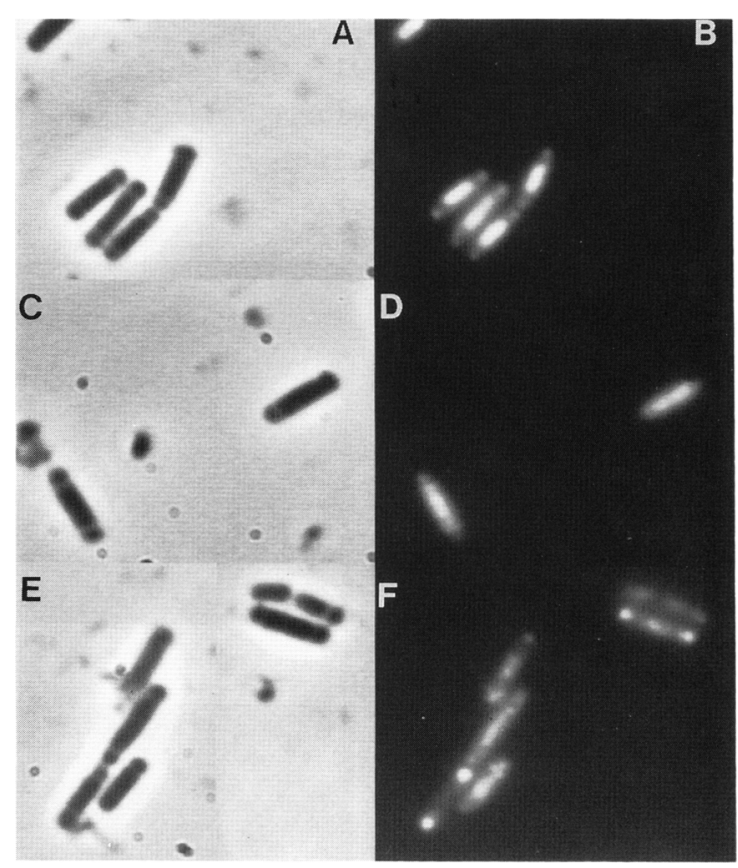

Figure 4. Rescue of prespore chromosome partitioning postseptation in a spoIIIE spoIIGB double mutant. Strain 902 (spoIIIE36 spoIIGB901) was induced to sporulate. After $3.5 \mathrm{hr}$ $\left(t_{3.5}\right)$ the culture was divided into three portions, which were infected with the appropriate phage or left uninfected. Phasecontrast $(A, C, E)$ and fluorescence $(B, D, F)$ micrographs of representative fields of cells are shown. $(A, B)$ Control culture (uninfected) at the time of infection $\left(t_{3.5}\right)$. Asterisks indicate disporic cells (i.e., which have a septum at both poles of the cell). $(C, D)$ Two hours after infection with $\phi 105 J 106\left(t_{5.5}\right) \cdot\{E, F)$ Composite images $2 \mathrm{hr}$ after infection with $\phi 105) 115\left(t_{5.5}\right)$. Microscopic magnification, $2000 \times$. 
partitioning. To test this we made use of a strain (SU105) carrying a mutation in the $\operatorname{divIB}$ gene, which is required for septation in both vegetative and sporulating cells (Harry et al. 1993). This mutation was chosen because it reduces septation severely even at the normal growth temperature, $37^{\circ} \mathrm{C}$. During vegetative growth at this temperature, the mutant produced many long filaments that were devoid of septa (Fig. 5A), but, as expected, chromosome partitioning occurred more or less normally; the nucleoids were regularly distributed throughout the cell filaments (Fig. 5B). Thus, chromosome partitioning in vegetative $B$. subtilis does not require septation. After the induction of sporulation, chromosome partitioning was more irregular (Fig. 5C,D) and no condensed prespore nucleoids were evident. Similar results have been obtained with mutants affected in other cell division genes ( $f t s Z$ and $p b p B$; P.J. Lewis, R.A. Daniel, and J. Errington, unpubl.). These results strongly suggest that proper prespore nucleoid partitioning requires formation of the spore septum, although it is formally possible that the septum is needed to maintain the prespore chromosome in a condensed state.

\section{Discussion}

Seven class I spoIIIE mutations, which specifically prevent prespore chromosome partitioning, were all found to affect the carboxy-terminal half of SpoIIIE. Mutagenesis of the amino-terminal coding portion of spoIIIE gave
A

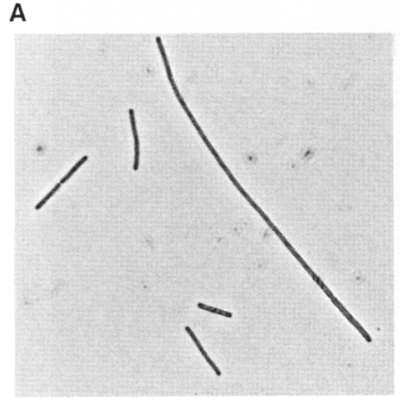

C

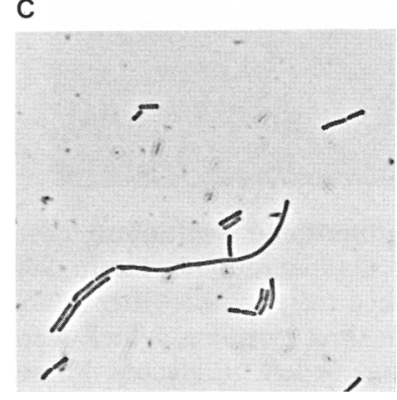

B

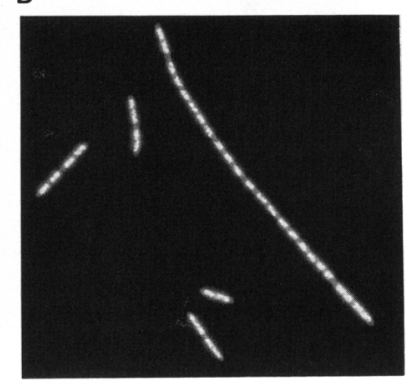

o

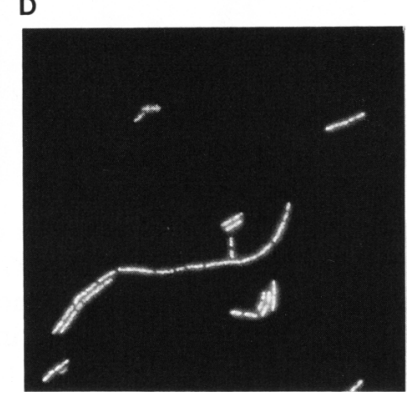

Figure 5. Effect of the divIB105 septum initiation mutation on DNA partitioning during vegetative growth and sporulation. $(A, C)$ Phase-contrast images of $B$. subtilis SU105 cells grown at $37^{\circ} \mathrm{C}$, taken at the time of initiation of sporulation and $3 \mathrm{hr}$ later, respectively. $(B, D)$ Fluorescence micrographs of the same cells stained with DAPI. Microscopic magnification, $1250 \times$. numerous new alleles of spoIIIE, but all were class II except for two mutations that lay close to the distal end of the mutagenized segment. Thus, the domain responsible specifically for prespore chromosome partitioning probably does not extend far into the amino-terminal half of the protein. The carboxy-terminal region of SpollIE could be aligned over most of its length with four proteins that are essential for conjugative plasmid DNA transfer in Streptomyces (Figs. 1 and 2). Furthermore, the most highly conserved portions of SpoIIIE, defined by comparison with the proteins encoded by two closely related genes from other bacteria, coincided generally with the regions of highest conservation among the Tra proteins (Fig. 2). It is thus tempting to speculate that the functions of these proteins are related.

Although conjugation is widespread in bacteria, little is known about the mechanisms of conjugative DNA transfer other than those of $\mathrm{F}$ and related systems of $E$. coli (Wilkins and Lanka 1993), which require the products of many genes (Frost et al. 1994). Conjugation mediated by plasmids in Streptomyces is likely to be quite different from that of $F$ because only a single plasmidencoded function is needed for DNA transfer (Hopwood and Kieser 1993). Perhaps the need for complicated mechanisms with which to bring together donor and recipient $E$. coli is unnecessary in Streptomyces because of the sedentary mycelial habit of these organisms; donor and recipient presumably interact only when the growing mycelia from adjacent colonies overlap. DNA transfer during sporulation almost certainly involves doublestranded molecules, unlike the single-stranded transfer of DNA mediated by F. However, there is no reason to suppose that other conjugation systems might not work in a double-stranded manner (Wilkins and Lanka 1993). The apparent simplicity of the Streptomyces system, including the absence of DNA helicases, nicking enzymes, and so forth, would be compatible with a doublestranded DNA transfer process.

We showed previously that spoIIIE mutants were deficient in prespore chromosome partitioning, but our observations gave no clue as to the relative timing of partitioning and septation. The similarity between SpoIIIE and the Tra proteins suggested that the later stages of partitioning might proceed essentially through the septum, by analogy to the process of conjugative DNA transfer. In wild-type sporulating cultures, we found that the DNA content of cells with visible asymmetric septa was highly variable. At the lower end of the range, the DNA content resembled that of spoIIIE mutant cells $(\sim 30 \%$ of a chromosome equivalent). A range of values intermediate between $30 \%$ and fully segregated chromosomes was visible in both a wild-type strain and in a spoIIG mutant. The spoIIIE phenotype, with the prespore chromosome bisected by the polar septum thus represents an intermediate in the normal partitioning process. The idea that prespore chromosome translocation can occur through a nearly completed septum was tested directly. Sporulating cells of a spoIIIE mutant were allowed to accumulate in a state in which their chromosomes were trapped in the partially segregated 
state by polar septa. Previous electron microscopic examination of such cells had shown that the septa were complete within the limits of detection $(\mathrm{Wu}$ and Errington 1994). The septum probably closes to the point where it completely seals off the large and small compartments because we showed previously that $\sigma^{\mathrm{F}}$ activity is correctly restricted to the prespore compartment in the spoIIIE36 mutant (Wu and Errington 1994). Following infection with a phage carrying the wild-type spoIIIE gene, prespore chromosome partitioning was rescued in a substantial proportion of the cells, confirming that the chromosome can pass through a septum that is effectively completed. The dependence of prespore chromosome partitioning on septation (Fig. 5) suggests that an interaction with the septum is an important function of SpoIIIE, presumably mediated by its hydrophobic, amino-terminal domain.

Figure 6 shows a schematic model for prespore chromosome partitioning and the action of SpolIIE. We suggest that partitioning is a two-step process. In the first step, the septum forms, trapping a segment of DNA in the small compartment. The remainder of the chromosome is then translocated through the septum in a SpoIIIE-dependent manner. It is evident that the second step in partitioning bears a striking resemblance to plasmid-mediated conjugation: DNA is transferred between two bacteria that are joined by a narrow cytoplasmic pore. The functional and morphological similarities between these processes have interesting evolutionary implications, and comparative studies of the two processes are likely to be enlightening. Moreover, the finding of apparent chromosomal homologs of SpolIIE in diverse bacteria suggests that the postseptational partitioning machinery may have functions aside from the specialized situation in sporulating cells.

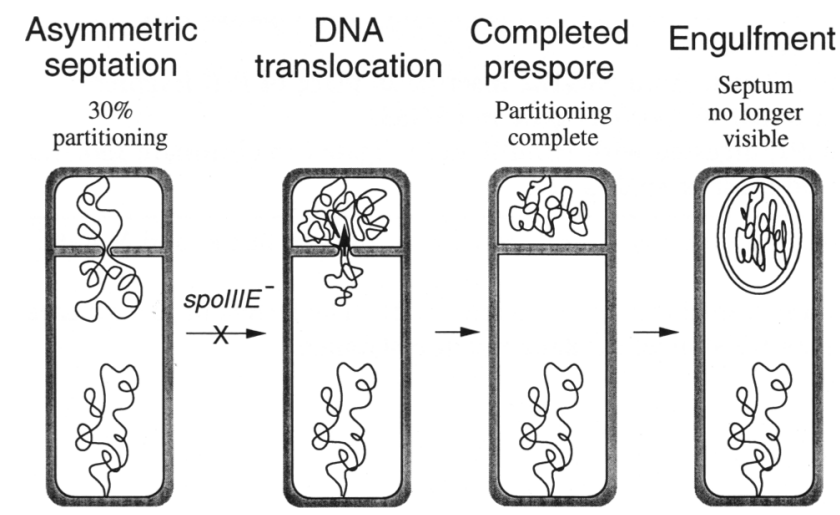

Figure 6. Proposed mechanism of chromosome partitioning into the prespore. Formation of the asymmetric septum traps $\sim 30 \%$ of the prespore chromosome in the small compartment. The remainder of the chromosome is then translocated across the septum, in a SpoIIIE-dependent manner /Wu and Errington 1994), producing small compartments with increasing amounts of DNA. Toward the end of the DNA translocation process or after translocation is complete continued development of the spore (involving engulfment by the mother cell) results in the disappearance of polar septa.

\section{Materials and methods}

Bacterial strains, plasmids, and media

The B. subtilis strains used in this study are listed in Table 3, along with the plasmids used in this work and their construction. E. coli strain DH5 $\alpha\left[\mathrm{F}^{-}\right.$endA1 hsdR17 supE44 $\lambda^{-}$thi-1 recA1 gytA96 relA1 $\triangle$ (lacZYA-argF)U169 \$80dlac $\Delta$ (lacZ)M15; GIBCO-BRL] was used for plasmid constructions. A spoIIIG' 'lacZ fusion was introduced into spolIIE mutant strains by transformation with plasmid pSG139 and selection for chloramphenicol resistance.

Solid media used for growing $B$. subtilis were nutrient agar (Oxoid) and lactose glutamate minimal (LGM) agar (Piggot 1973). Chloramphenicol $(5 \mu \mathrm{g} / \mathrm{ml})$, kanamycin $(5 \mu \mathrm{g} / \mathrm{ml})$, erythromycin $\{1 \mu \mathrm{g} / \mathrm{ml})$, and lincomycin $(25 \mu \mathrm{g} / \mathrm{ml})$, or $0.01 \% \mathrm{X}-\mathrm{gal}$, were added as required. Media for growing $E$. coli were $2 \times$ TY (Sambrook et al. 1989) and nutrient agar (Oxoid), supplemented with ampicillin $\{100 \mu \mathrm{g} / \mathrm{ml}\}$, as required.

\section{General methods}

B. subtilis cells were made competent for transformation with DNA by the method of Anagnostopoulos and Spizizen (1961), as modified by Jenkinson (1983). The spo mutants were made isogenic by transforming $B$. subtilis strain CU267, selecting for $\mathrm{Ilv}^{+} \mathrm{Leu}^{+}$transformants, and screening for $\mathrm{Spo}^{-}$congressants on LGM agar plates. The congressants were checked for complementation with a recombinant transducing phage $\phi 105 \mathrm{~J} 115$ (East and Errington 1989). B. subtilis chromosomal DNA was prepared by a scaled-down method based on the one described by Errington (1984). DNA manipulations and $E$. coli transformations were carried out using standard methods (Sambrook et al. 1989).

\section{Induction of sporulation}

B. subtilis cells grown in hydrolyzed casein growth media at $37^{\circ} \mathrm{C}$ were induced to sporulate by the resuspension method of Sterlini and Mandelstam (1969), as modified by Partridge and Errington (1993). Times (hr) after resuspension of cells in the starvation medium were denoted $t_{0}, t_{1}$, and so forth.

\section{Cloning and sequencing spoIIIE alleles}

To sequence the spoIIIE mutations, each mutation was transferred from the $B$. subtilis chromosome to integration plasmids by the method of plasmid integration and excision (Niaudet et al. 1982; Errington 1990). Mutant strains were transformed with integration plasmids containing either the promoter-proximal (pSG255) or promoter-distal (pSG801) portions of the wild-type gene, selecting for the appropriate antibiotic resistance. Chromosomal DNA was then prepared from suitable transformants (either $\mathrm{Spo}^{+}$or $\mathrm{Spo}^{-}$, depending on the restriction endonuclease used for plasmid recoveryl, and the integrated plasmids were recovered by digestion with appropriate restriction endonucleases, end-filling (when necessary), religation, and transformation into $E$. coli with selection for ampicillin resistance. Plasmid DNA from E. coli transformants was subjected to restriction endonuclease analysis. Individuals with the correct restriction patterns were then transformed into both the wildtype strain, SG38, and the parental spoIIIE mutant to determine whether or not they contained the mutant allele. PCR amplification of the spoIIIE913 mutant allele was done with oligonucleotides $5^{\prime}$-AAGGTGATGCATATGGCAAAGAAA-3' and 5'. GTTAGCCCCTACAGG-3'.

Double-stranded plasmid DNA or PCR-amplified DNA was 
Wu et al.

Table 3. Bacterial strains and plasmids

\begin{tabular}{|c|c|c|}
\hline Strain & Relevent genotype $^{a}$ & Construction, source, or reference ${ }^{b}$ \\
\hline \multicolumn{3}{|l|}{ B. subtilis } \\
\hline CU267 & leuB16 ilvB2 trpC2 & $\begin{array}{l}\text { S.A. Zahler (Genetics and Development Department, Cornell } \\
\text { University, Ithaca, NY) }\end{array}$ \\
\hline SG10 & purA16 divIVB1 & Reeve et al. (1973) \\
\hline SG38 & $\operatorname{trp} C 2$ amyE & Errington and Mandelstam (1986) \\
\hline SU105 & $\operatorname{trp} C 2$ thy $A$ thy $B$ divIB105 & Harry et al. (1993) \\
\hline $36.3(\mathrm{NG} 1.67)^{\mathrm{c}}$ & trpC2 spoIIIE36 & Piggot (1973) \\
\hline $47.4(\mathrm{NG} 8.17)^{\mathrm{c}}$ & trpC2 spoIIIE47 & Piggot (1973) \\
\hline 82.1 & trpC2 spoIIIE82 & Hranueli et al. (1974) \\
\hline 601.6 & trpC2 spoIIIE601 & Deadman (1986) \\
\hline 602.6 & trpC2 spollIE602 & Deadman (1986) \\
\hline 603.6 & trpC2 spollIE603 & Deadman (1986) \\
\hline 604.6 & trpC2 spoIIIE604 & Deadman (1986) \\
\hline $629(\mathrm{~A} 3)^{\mathrm{c}}$ & trpC2 spollIE2 ${ }^{d}$ & Piggot (1973) \\
\hline 644 & trpC2 spoIIIE644 & Foulger and Errington (1989) \\
\hline 647 & $\operatorname{trp} C 2 \Omega$ (spoIIIE::aphA-3)647 & Wu and Errington (1994) \\
\hline 649 & trpC2 spoIIIE 649 & J. Errington (unpub.) \\
\hline 687 & $\operatorname{trpC2} \Omega($ spoIIIG'-lacZ erm C)687 & Partridge et al. (1991) \\
\hline 901 & $\operatorname{trp} C 2 \Omega($ spolIGA::aph-A3)901 & pSG814 DNA $\rightarrow$ SG38 (K) \\
\hline 902 & $\begin{array}{l}\operatorname{trp} C 2 \text { spoIIIE36 } \\
\quad \Omega(\text { spoIIGA::aph-A3)901 }\end{array}$ & $901 \mathrm{DNA} \rightarrow \mathrm{SG} 38(\mathrm{~K})$ \\
\hline 911 & $\operatorname{trpC2}$ spoIIIE911 & 923 DNA $\rightarrow$ CU267 (ILV) \\
\hline 913 & trpC2 spoIIIE913 & 921 DNA $\rightarrow$ CU267 (ILV) \\
\hline 921 & trpC2 spollIE::pSG255 spoIIIE 913 cat & NTG-mutagenized pSG255 $\rightarrow$ SG38 $|\mathrm{C}|$ \\
\hline 923 & $\begin{array}{l}\text { trpC2 } \Omega \text { (spoIIIG'-lacZ ermC)687 } \\
\quad \text { spoIIIE::pSG255 spoIIIE911 cat }\end{array}$ & NTG-mutagenized pSG255 $\rightarrow 687$ (C) \\
\hline \multicolumn{3}{|l|}{ Plasmids } \\
\hline pSG2 & bla cat & Fort and Errington (1985) \\
\hline pSG91 & bla cat spoIIGAB spoIIIG646 & Foulger and Errington $(1989)$ \\
\hline pSG122 & bla aph-A3 & Daniel and Errington (1993) \\
\hline pSG139 & bla cat spoIIIG'-'lacZ & Foulger and Errington (1989) \\
\hline pSG203 & bla cat spoIIIE644 (1-3491) & Butler and Mandelstam (1987) \\
\hline pSG209 & bla cat spoIIIE (3040-3491) & Butler and Mandelstam (1987) \\
\hline pSG253 & bla cat spoIIIE644 (2265-3491) & Foulger and Errington (1989) \\
\hline pSG255 & bla cat spoIIIE (598-2264) & $\begin{array}{l}1.75 \mathrm{~kb} \text { EcoRV fragment from pSG } 203 \text { cloned into } \\
\text { SmaI-digested pSG2 (D. Foulger, unpub) }\end{array}$ \\
\hline pSG801 & bla cat spoIIIE (2265-3491) & $\begin{array}{l}\text { EcoRI, EcoRV, double digest of chromosomal DNA from } \\
\text { SG38::pSG253 (Spo- transformant), end-repaired and } \\
\text { religated }\end{array}$ \\
\hline pSG814 & bla cat $\Omega$ (spoIIGA::aph-A3) 901 & $\begin{array}{l}a p h-A 3 \text { gene from pSG } 122 \text { inserted in place of PstI fragment } \\
\text { internal to spoIIGA gene in pSG } 832\end{array}$ \\
\hline pSG832 & bla cat spoIIGA & $\begin{array}{l}\text { pSG91, digested with HindIII and religated to eliminate spoIIIG } \\
\text { and most of spoIIGAB }\end{array}$ \\
\hline
\end{tabular}

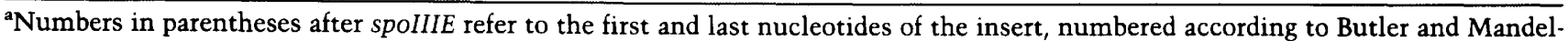
stam (1987) as corrected by Foulger and Errington (1989).

${ }^{b}$ For newly constructed strains, the arrow indicates that the DNA was transformed into the recipient strain. The letters in parentheses indicate the selection imposed: $\mathrm{ILV}, \mathrm{Ilv}^{+}$, and $\mathrm{Leu}^{+},(\mathrm{C})$ chloramphenicol resistance $;(\mathrm{K})$ kanamycin resistance.

'Original isolation numbers of strains containing the spoIIIE mutation.

${ }^{d}$ Previously assigned to the spoIIIB locus (Piggot and Coote 1976).

sequenced directly by the chain termination method of Sanger et al. (1977) with Sequenase (v. 2.0), using the Reagent Kit for Sequencing with Sequenase (U.S. Biochemical) and ${ }^{35} \mathrm{~S}$-labeled nucleotides (Amersham), essentially as described by the suppliers. Synthetic oligonucleotides were made to a final concentra-

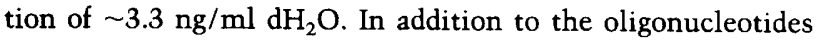
used for the PCR reactions, the following oligonucleotides were used for sequencing: M13 universal forward sequencing primer, 5'-ACTGGCCGTCGTTTTAC-3'; M13 universal reverse sequencing primer, 5'-AACAGCTATGACCATG-3'; 5'-GGTC-
ATAGGAGGAGCAG-3'; 5'-GCGGGCGAAACCGCATGAAGTGA3-'; 5'-CCTGTAAACGGCTGC-3'. Two independently amplified products carrying the spoIIIE 913 mutation were sequenced.

\section{Localized mutagenesis of spoIIIE}

E. coli strain DH5a containing plasmid pSG255, harboring the amino-terminal coding region of spoIIIE, was mutagenized with NTG. A culture containing cells from a single colony of $E$. coli 
strain DH5 $\alpha$ (pSG255) was grown overnight at $37^{\circ} \mathrm{C}$ in $2 \times \mathrm{TY}$ containing ampicillin. A $1-\mathrm{ml}$ portion of the overnight culture was used to inoculate $20 \mathrm{ml}$ of the same medium and grown at $37^{\circ} \mathrm{C}$ with shaking until the $\mathrm{OD}_{600}$ was 1.0 ( $\left.\sim 90 \mathrm{~min}\right)$. Then, $2.5-\mathrm{ml}$ portions of the culture were removed and mixed with equal volumes of warm $2 \times$ TY containing $400-600 \mu \mathrm{g}$ of NTG. The cultures were incubated for $15 \mathrm{~min}$ at $37^{\circ} \mathrm{C}$ with shaking and then centrifuged to collect the cells. The cell pellets were washed twice in warm $2 \times$ TY containing ampicillin and resuspended in $2.5 \mathrm{ml}$ of the same medium. The cells were grown for an additional $4.5 \mathrm{hr}$ with shaking; then, a $2-\mathrm{ml}$ portion of the culture was used for isolating plasmid DNA, and the rest was frozen in $10 \%$ glycerol and stored at $-70^{\circ} \mathrm{C}$. The plasmid mixtures containing mutagenized pSG255 were then transformed into the wild-type strain SG38, with selection for resitance to chloramphenicol, and $\mathrm{Spo}^{-}$transformants were isolated and purified. The plasmid mixtures were also transformed into strain 687 , containing a spoIIIG'-'lacZ fusion, with selection for resistance to both erythromycin and chloramphenicol. Transformants that were white in the presence of X-gal were isolated.

\section{Sequence similarity searches and alignments}

Proteins similar to SpoIIIE were identified in protein sequence data bases using the programs BLAST (Altschul et al. 1990) and FASTA (Pearson and Lipman 1988). Sequence alignments were generated manually, based on output from the MACAW program (Schuler et al. 1991).

\section{Visualization of spore septa and DNA}

Samples of sporulating cultures $(0.65 \mathrm{ml})$, taken $75-90 \mathrm{~min}$ after starvation, were prepared for visualization of septa as follows: The sample was chilled, and $\mathrm{NaN}_{3}$ was added (final concentration $0.1 \% \mathrm{wt} / \mathrm{vol}$ ). The cells were harvested (microcentrifuge, 3 $\min )$, resuspended in ice-cold $70 \%(\mathrm{vol} / \mathrm{vol})$ ethanol, and stored at $4^{\circ} \mathrm{C}$ overnight. The cells were harvested as above, resuspended in sterile distilled water, and viewed immediately by spreading a 2- to 5- $\mu$ l sample of the suspension on a coverslip and inverting this onto a glass slide carrying a 5- $\mu$ l drop of $50 \%$ (vol/vol) glycerol containing $1 \mu \mathrm{g} / \mathrm{ml}$ of 4,6-diamidino-2-phenylindole (DAPI; Sigma). Coverslips were pretreated with $0.01 \%$ polylysine (Sigma) and air-dried. The preparations were examined on a Zeiss Axiophot photomicroscope, equipped with an Optovar, and digital images were obtained and analyzed as described previously (Wu and Errington 1994). The minicell strain, SG10, was grown in Oxoid Penassay broth to late exponential phase. Samples were treated and viewed as for sporulating cells.

\section{Postseptational partitioning of prespore DNA by phage infection}

The phage cloning vector $\phi 1051106$ and its spoIIIE ${ }^{+}$derivative $\phi 105$ J115 (East and Errington 1989) were purified and titerd by standard methods (Errington 1990). Strain 902 was induced to sporulate as described above. After $3.5 \mathrm{hr}$, the culture was divided into three aliquots. Two aliquots were infected with phage preparations ( $\phi 105$ J106 or $\phi 105 J 115)$ at a multiplicity of infection of $\sim 5$. The third aliquot was uninfected. Samples taken at the time of infection or at intervals thereafter were fixed with ethanol and prepared for phase-contrast and fluorescence microscopy as described above. A standard preparation of cells with single completed nucleoids was mixed with each sample to provide an internal standard with which to measure the DNA content of the prespore compartment (Hauser and Errington 1995). Sporulating cells were defined as those in which prespore septa were present (as judged by phase-contrast microscopy). Cells in which the DNA fluorescence of the prespore compartment was brighter than that of the central compartment were considered to have been at least partially rescued following phage infection, a deliberately conservative definition.

\section{Acknowledgments}

We thank Dr. A.J. Day for assistance with the amino acid alignments, David Foulger for plasmid constructions, Tobias Keiser for helpful discussions and for communicating unpublished amino acid sequences, and R.G. Wake and M.D. Yudkin for helpful discussions and comments on the manuscript. This work was supported by grants from the Science and Engineering Research Council. L.J.W. was the recipient of a K.C. Wong Scholarship and an EPA Cephalosporin Trust award. R.A. was supported by a Postdoctoral Fellowship of the European Community. P.J.L. was supported by a Science and Engineering Research Council/North Atlantic Treaty Organization fellowship. P.M.H. was supported by fellowships from the Swiss National Fund for Scientific Research and the European Molecular Biology Organization.

The publication costs of this article were defrayed in part by payment of page charges. This article must therefore be hereby marked "advertisement" in accordance with 18 USC section 1734 solely to indicate this fact.

\section{References}

Altschul, S.F., W. Gish, W. Miller, E.W. Myers, and D.J. Lipman. 1990. Basic local alignment search tool. I. Mol. Biol. 215: 403-410.

Anagnostopoulos, C. and J. Spizizen. 1961. Requirements for transformation in Bacillus subtilis. I. Bacteriol. 81: 741-746.

Beall, B. and J. Lutkenhaus. 1991. FtsZ in Bacillus subtilis is required for vegetative septation and for asymmetric septation during sporulation. Genes \& Dev. 5: 447-455.

. 1992. Impaired cell division and sporulation of a Bacil. lus subtilis strain with the ftsA gene deleted. $/$. Bacteriol. 174: 2398-2403.

Beall, B., M. Lowe, and J. Lutkenhaus. 1988. Cloning and characterization of Bacillus subtilis homologs of Escherichia coli cell division genes $f t s Z$ and $f t s A$. I. Bacteriol. 170: 4855-4864.

Butler, P.D. and J. Mandelstam. 1987. Nucleotide sequence of the sporulation operon, spollIE, of Bacillus subtilis. I. Gen. Microbiol. 133: 2359-2370.

Daniel, R.A. and J. Errington. 1993. Cloning, DNA sequence, functional analysis and transcriptional regulation of the genes encoding dipicolinic acid synthesis required for sporulation in Bacillus subtilis. I. Mol. Biol. 232: 468-483.

Deadman, M.E. 1986. "Genetics and sequencing of an operon concerned in sporulation of Bacillus subtilis." M.Sc. thesis, University of Oxford, Oxford, UK.

Donachie, W.D. 1993. The cell cycle of Escherichia coli. Annu. Rev. Microbiol. 47: 199-230.

East, A.K. and J. Errington. 1989. A new bacteriophage vector for cloning in Bacillus subtilis and the use of $\phi 105$ for protein synthesis in maxicells. Gene 81: 35-43.

Errington, J. 1984. Efficient Bacillus subtilis cloning system using bacteriophage vector $\phi 105$ J9. I. Gen. Microbiol. 130: 2615-2628.

1990. Gene cloning techniques. In Molecular biological methods for Bacillus (ed. C.R. Harwood and S.M. Cutting), pp. 175-220. Wiley, Chichester, UK.

Errington, J. and J. Mandelstam. 1986. Use of a lacZ gene fusion 
to determine the dependence pattern of sporulation operon spoIIA in spo mutants of Bacillus subtilis. J. Gen. Microbiol. 132: $2967-2976$.

Fort, P. and J. Errington. 1985. Nucleotide sequence and complementation analysis of a polycistronic sporulation operon, spoVA, in Bacillus subtilis. I. Gen. Microbiol. 131: 10911105.

Foulger, D. and J. Errington. 1989. The role of the sporulation gene spoIIIE in the regulation of prespore-specific gene expression in Bacillus subtilis. Mol. Microbiol. 3: 1247-1255.

Frost, L.A., K. Ippen-Ihler, and R.A. Skurray. 1994. Analysis of the sequence and gene products of the transfer region of the F sex factor. Microbiol. Rev. 58: 162-210.

Hagège, J., J.-L. Pernodet, G. Sezonov, C. Gerbaud, A. Friedmann, and M. Guérineau. 1993. Transfer functions of the conjugative integrating element pSAM2 from Streptomyces ambofaciens: Characterization of a kil-kor system associated with transfer. I. Bacteriol. 175: 5529-5538.

Harry, E.J., B.J. Stewart, and R.G. Wake. 1993. Characterization of mutations in divIB of Bacillus subtilis and cellular localization of the DivIB protein. Mol. Microbiol. 7: 611-621.

Hauser, P.M. and J. Errington. 1995. Characterization of cell cycle events during the onset of sporulation in Bacillus subtilis. J. Bacteriol. (in press).

Hiraga, S. 1992. Chromosome and plasmid partitioning in Escherichia coli. Annu. Rev. Biochem. 61: 283-306.

Hiraga, S., H. Niki, T. Ogura, C. Ichinose, H. Mori, B. Ezaki, and A. Jaffe. 1989. Chromosome partitioning in Escherichia coli: Novel mutants producing anucleate cells. I. Bacteriol. 171: 1496-1505.

Hitchins, A.D. and R.A. Slepecky. 1969. Bacterial spore formation as a modified procaryotic cell division. Nature 223: 804-807.

Hopwood, D.A. and T. Kieser. 1993. Conjugative plasmids of Streptomyces. In Bacterial coniugation (ed. D.B. Clewell), pp. 293-311. Plenum Press, New York.

Hranueli, D., P.J. Piggot, and J. Mandelstam. 1974. Statistical estimate of the total number of operons specific for Bacillus subtilis sporulation. J. Bacteriol. 119: 684-690.

Jenkinson, H.F. 1983. Altered arrangement of proteins in the spore coat of a germination mutant of Bacillus subtilis. $I$. Gen. Microbiol. 129: 1945-1958.

Kataoka, M., T. Seki, and T. Yoshida. 1991. Five genes involved in self-transmission of pSN22, a Streptomyces plasmid. $I$. Bacteriol. 173: 7975-7981.

Kendall, K.J. and S.N. Cohen. 1988. Complete nucleotide sequence of the Streptomyces lividans plasmid pIJ101 and correlation of the sequence with genetic properties. J. Bacteriol. 170: $4634-4651$.

Levin, P.A. and R. Losick. 1994. Characterization of a cell division gene from Bacillus subtilis that is required for vegetative and sporulation septum formation. J. Bacteriol. 176: $1451-1459$.

Lewis, P.J., S.R. Partridge, and J. Errington. 1994. o factors, asymmetry, and the determination of cell fate in Bacillus subtilis. Proc. Natl. Acad. Sci. 91: 3849-3853.

Margolis, P., A. Driks, and R. Losick. 199l. Establishment of cell type by compartmentalized activation of a transcription factor. Science 254: 562-565.

Miller, S., E.C. Pesci, and C.L. Pickett. 1994. Genetic organization of the region upstream from the Campylobacter jejuni flagellar gene flhA. Gene 146: 31-38.

Niaudet, B., A. Goze, and S.D. Ehrlich. 1982. Insertional mutagenesis in Bacillus subtilis: Mechanism and use in gene cloning. Gene 19: 277-284.

Osburne, M.S. and A.L. Sonenshein. 1976. Behavior of a tem- perate bacteriophage in differentiating cells of Bacillus sub tilis. J. Virol. 19: 26-35.

Oswald, W. and D. Thiele. 1993. A sponulation gene in Coxiella burnetii? J. Vet. Med. Ser. B 40: 366-370.

Partridge, S.R. and J. Errington. 1993. The importance of morphological events and intercellular interactions in the regulation of prespore-specific gene expression during sporulation in Bacillus subtilis. Mol. Microbiol. 8: 945-955.

Partridge, S.R., D. Foulger, and J. Errington. 1991. The role of $\sigma^{\mathrm{F}}$ in prespore-specific transcription in Bacillus subtilis. Mol. Microbiol. 5: 757-767.

Pearson, W.R. and D.J. Lipman. 1988. Improved tools for biological sequence alignment. Proc. Natl. Acad. Sci. 85: 2444 2448.

Piggot, P.J. 1973. Mapping of asporogenous mutations of Bacillus subtilis: A minimum estimate of the number of sporulation operons. I. Bacteriol. 114: 1241-1253.

Piggot, P.J. and J.G. Coote. 1976. Genetic aspects of bacterial endospore formation. Bacteriol. Rev. 40: 908-962.

Reeve, J.N., N.H. Mendelson, S.I. Coyne, L.L. Hallock, and R.M. Cole. 1973. Minicells of Bacillus subtilis. I. Bacteriol. 114: 860-873.

Ryter, A. 1965. Etude morphologique de la sporulation de $B a$ cillus subtilis. Ann. Inst. Pasteur 108: 40-60.

Sambrook, J., E.F. Fritsch, and T. Maniatis. 1989. Molecular cloning: A laboratory manual. Cold Spring Harbor Laboratory Press, Cold Spring Harbor, New York.

Sanger, F., S. Nicklen, and A.R. Coulsen. 1977. DNA sequencing with chain terminating inhibitors. Proc. Natl. Acad. Sci. 74: $5463-5467$

Saraste, M., P.R. Sibbald, and A. Wittinghofer. 1990. The P-loop-a common motif in ATP- and GTP-binding proteins. Trends Biochem. Sci. 15: 430-434.

Schuler, G.D., S.F. Altschul, and D.J. Lipman. 1991. A workbench for multiple alignment construction and analysis. Proteins: Structure, Function, Genet. 9: 180-190.

Setlow, B., N. Magill, P. Febbroriello, L. Nakhimovsky, D.E. Koppel, and P. Setlow. 1991. Condensation of the forespore nucleoid early in sporulation of Bacillus species. I. Bacteriol. 173: 6270-6278.

Sterlini, J.M. and J. Mandelstam. 1969. Commitment to sporulation in Bacillus subtilis and its relationship to the development of actinomycin resistance. Biochem. J. 113: 29-37.

Tomura, T., H. Kishino, K. Doi, T. Hara, S. Kuhara, and S. Ogata. 1993. Sporulation-inhibitory gene in pock-forming plasmid pSAl.1 of Streptomyces azureus. Biosci. Biotechnol. Biochem. 57: 438-443.

van Helvoort, J.M.L.M. and C.L. Woldringh. 1994. Nucleoid partitioning in Escherichia coli during steady state growth and upon recovery from chloramphenicol treatment. Mol. Microbiol. 13: $577-583$.

Walker, J.E., M. Saraste, M.J. Runswick, and N.J. Gay. 1982. Distantly related sequences in the $\alpha$ - and $\beta$-subunits of ATP synthase, myosin, kinases and other ATP-requiring enzymes and a common nucleotide binding fold. $E M B O J$. 1: 945-951.

Wilkins, B. and E. Lanka. 1993. DNA processing and replication during plasmid transfer between gram-negative bacteria. In Bacterial conjugation (ed. D.B. Clewell), pp. 105-136. Plenum Press, New York.

Wu, L.J. and J. Errington. 1994. Bacillus subtilis SpoIIIE protein required for DNA segregation during asymmetric cell division. Science 264: 572-575.

Yanouri, A., R.A. Daniel, J. Errington, and C.E. Buchanan. 1993. Cloning and sequencing of the cell division gene $p b p B$, which encodes penicillin-binding protein $2 \mathrm{~B}$ in Bacillus subtilis. J. Bacteriol. 175: 7604-7616. 


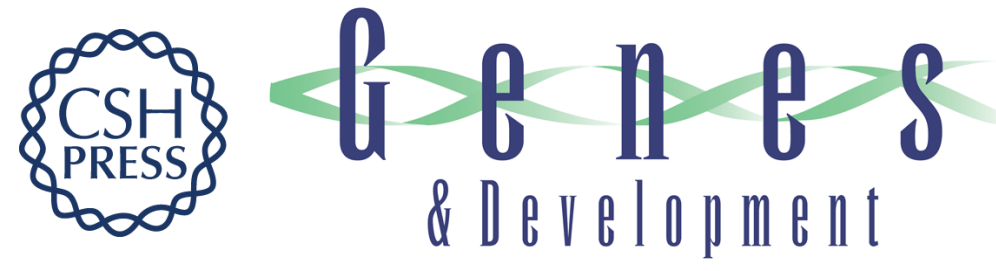

\section{A conjugation-like mechanism for prespore chromosome partitioning during sporulation in Bacillus subtilis.}

L J Wu, P J Lewis, R Allmansberger, et al.

Genes Dev. 1995, 9:

Access the most recent version at doi:10.1101/gad.9.11.1316

References This article cites 47 articles, 23 of which can be accessed free at:

http://genesdev.cshlp.org/content/9/11/1316.full.html\#ref-list-1

License

Email Alerting

Service

Receive free email alerts when new articles cite this article - sign up in the box at the top right corner of the article or click here.

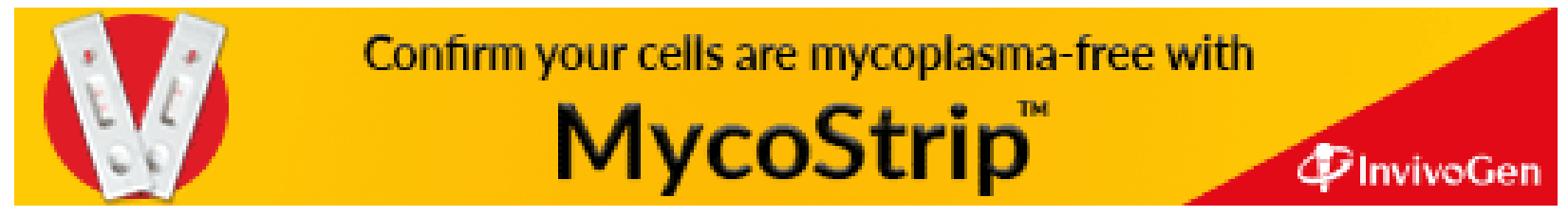

